\title{
ÉRZELEMSZABÁLYOZÁS - A MEGKÜZDÉS ÉS AZ ÉRZELMI INTELLIGENCIA TÜKRÉBEN: HÁROM FÜGGETLEN, DE MÉGIS ÁTFEDŌ ELMÉLETI ÉS KUTATÁSI TRADÍCIÓ
}

\author{
KÖKÖNYEI GYÖNGYI ${ }^{1,2}-$ KOCSEL NATÁLIA ${ }^{1,2,3}$ \\ ${ }^{1}$ ELTE Eötvös Loránd Tudományegyetem, Pszichológiai Intézet \\ ${ }^{2}$ SE-NAP-2 Genetikai Agyi Képalkotó Migrén Kutatócsoport, Semmelweis Egyetem \\ ${ }^{3}$ ELTE Eötvös Loránd Tudományegyetem, Pszichológiai Doktori Iskola \\ E-mail: kokonyei.gyongyi@ppk.elte.hu
}

Beérkezett: 2019. október 1. - Elfogadva: 2019. október 23.

\begin{abstract}
A megfelelöen kezelt és szabályozott érzelmi folyamatok kulcsfontosságú szerepet töltenek be a környezeti kihívásokhoz való sikeres alkalmazkodásban, és biztosítják az optimális mindennapi funkcionálást. Ennek alapján fontos megállapitani, hogy milyen helyzetekben és módokon, mely stratégiákon keresztül, valamint milyen képességek és készségek birtokában tudjuk hatékonyan kezelni érzelmeinket. Jelen elméleti összefoglaló fố célja, hogy az érzelemszabályozás folyamatmodelljének szemüvegén át vizsgálja az érzelemszabályozás, a megküzdés és az érzelmi intelligencia összefüggéseit és különbségeit. A teoretikus modellek felsorolásán kívül kézzelfogható példákon keresztül mutatjuk be a különböző folyamatokat és stratégiákat, és kitérünk az adaptivitás, maladaptivitás, valamint a pozitív érzelemszabályozás kérdéskörére is. Összefoglalónkat néhány kurrens kutatás empirikus eredményével zárjuk, és kiemeljük az ökológiai validitás fontosságának kérdéskörét az érzelemszabályozási kutatásokban.
\end{abstract}

Kulcsszavak: érzelemszabályozás, megküzdés, érzelmi intelligencia, folyamatmodell, rugalmasság 
Az érzelemszabályozás kérdésköre kapcsán mindig felmerül a kérdés, hogy vajon miben különbözik az érzelemfókuszú megküzdéstôl, és a szakirodalma, kutatásai és eredményei mennyiben mondanak többet az érzelmiintelligencia-modellek és kutatások „érzelmek kezelése” ágához képest. Jelen tanulmány célja, hogy az érzelmek kezelésérôl alkotott modellek és vizsgálatok tükrében ennek a három nagyobb elméleti/ kutatási tradíciónak a hasonlóságaira és különbségeire rámutasson. Érdemes elôrebocsátani azonban, hogy tanulmányunkban részletesebben az érzelemszabályozás folyamatmodelljére (Gross, 1998) és ezzel összefüggésben az érzelemszabályozó stratégiákra koncentrálunk.

Nem véletlen, hogy az érzelemszabályozási folyamatok vizsgálata több különbözô megközelítésben is hangsúlyos. A szabályozatlan érzelmi állapotok ugyanis nemcsak számos pszichopatológia jellemzô tünetei közé sorolhatók, hanem egyben a kialakulásuk szempontjából nonspecifikus rizikófaktoroknak is tekinthetôk. Ennek megfelelôen az érzelemszabályozási deficitek transzdiagnosztikus jellemzônek számítanak (Aldao, Nolen-Hoeksema és Schweitzer, 2010; Fernandez, Jazaieri és Gross 2016). Terápiás szempontból pedig kiemelendô, hogy a pszichológiai kezelések során vagy azt követôen - függetlenül a konkrét terápiás módszertôl - az érzelemszabályozó folyamatok változásai kéz a kézben járnak a tünetek változásával (Sloan és mtsai., 2017). Korábbi kutatások például azt mutatták, hogy az érzelemszabályozási képességek fejlesztésével párhuzamosan az egyetemisták körében csökkent a depresszív tünetek elôfordulása (Gortner, Rude és Pennebaker, 2006), a krónikus fájdalommal együtt élốk terápiája során pedig csökkent a fájdalomkatasztrofizálás, a depresszív tünetek száma és a fájdalom mindennapi életre gyakorolt negatív hatása is (Boersma és mtsai, 2019). Az érzelemszabályozás kedvező alakulása terápiás beavatkozásra borderline személyiségzavarban a kognitív és affektív tünetek, valamint az önsértố viselkedés csökkenésével társult (Gratz, Bardeen, Levy, Dixon-Gordon és Tull, 2015), míg túlevéses zavarban (binge eating disorder) az érzelemszabályozásban bekövetkezô pozitív terápiás változások falásrohamok elmaradását jósolták a terápiát követô 4 hónap múlva (Wallace, Masson, Safer és Von Ranson, 2014).

\section{ÉRZELEMSZABÁLYOZÁS ÉS MEGKÜZDÉS}

A mai érzelemszabályozás-kutatás jelentôs elôzményének tekinthetjük a stressz és megküzdés témakörében végzett kutatásokat, ill. elméleti munkákat (Gross, 1998). Megküzdésként definiálhatunk minden olyan célirányos, tudatos és szándékos kognitív vagy viselkedéses erôfeszítést, amelynek célja, hogy az erőforrásainkat felülmúló belsố vagy külsố hatásokat kezelni tudjuk (Lazarus, 1991; Lazarus és Opton, 1966). Elkülöníthetünk probléma- és érzelemfókuszú megküzdést. Logikusan adódik a következtetés, hogy az érzelemfókuszú megküzdés - amelynek célja elsôsorban a negatív érzelmek csillapítása - releváns az érzelemszabályozás témakörében. Számtalan példát lehetne felhozni ugyanakkor arra, hogy nemcsak a különbözô nehézségek, stresszorok kezeléséhez elengedhetetlen az érzelmeink szabályozása, hanem a mindennapi múködés inherens része is. Érzelemszabályozásnak tekinthetố például, ha visszafojtjuk nevetésünket egy olyan helyzetben, ahol muszáj komolynak maradnunk, vagy ha nem 
sírjuk el magunkat egy megható videó láttán, amelyet munkaidôben nézegetünk; vagy vicces gyermekkori történeteket mesélünk a gyermekünknek, aki éppen szomorkodik valami iskolai probléma miatt.

Érzelemszabályozás során tehát a mindennapokban jelentkezô pozitív és negatív érzelmek modulációja történik olyan helyzetekben is, amelyeket az egyén nem feltétlenül értékel úgy, hogy azok meghaladnák a képességeit vagy az erôforrásait (Gross, 1998). Éppen ezért nem meglepố, hogy az érzelmek szabályozásának kutatásában a stresszel való megküzdéstôl valamennyire „függetlenedő” irány is megjelent az 1990-es években, amely elsôsorban az érzelemszabályozás folyamatának, stratégiáinak és hatásainak megértését tûzte ki célul. Compas és munkatársai (2017) például úgy próbálnak különbséget tenni a megküzdés és az érzelemszabályozás között, hogy azt mondják, a megküzdés vagy pontosabban az érzelemfókuszú megküzdés az érzelmek szabályozásának azt a szeletét öleli fel, amely kifejezetten stresszhelyzetekben történik. Ugyanakkor nyilvánvalóan a megküzdés fogalma egyben tágabb fogalom is, mivel nem érzelmi célok nem érzelmi eszközökkel való elérését is magába foglalja. A megküzdési modellekrôl, fogalmakról és kutatásokról Oláh (2004) könyvfejezete ad kitûnô áttekintést. Ugyanakkor - ahogy már jeleztük - az érzelemszabályozás kérdésköre nem szúkíthetô le csak a stresszhelyzetekre, így azoktól függetlenül is vizsgálható, tesztelhetô.

Az érzelemszabályozás történhet stresszes és nem stresszes környezetben egyaránt, és a - megküzdéstôl eltérôen - nemcsak szándékos és kontrollált, hanem automatikus folyamatokat is magába foglalhat (Gross, 1998). Tudatosan szabályozzuk érzelmeinket például akkor, ha újra végiggondoljuk az elózô napi veszekedést a párunkkal, és átkeretezzük azt, vagy éppen egy szürke, hideg téli napon jobban szeretnénk érezni magunkat, ezért feldobjuk magunkat a legutóbbi nyaralás képeinek nézegetésével vagy az emlékek felidézésével. Rendszeresen (rutinszerúen) alkalmazott érzelemszabályozási stratégiáink viszont könnyedén válhatnak automatizmussá, így például nem feltétlenül vagyunk tudatában annak, hogy azért gyújtottunk rá egy újabb cigarettára, mert kellemetlenné vált számunkra egy helyzet (Compas és mtsai, 2017), vagy észre sem vettük, de már megint belekerültünk egy rágódási „körbe” (Watkins és Nolen-Hoeksema, 2014).

\section{ÉRZELEMSZABÁLYOZÁS: DEFINÍCIÓK ÉS MODELLEK}

Az érzelemszabályozás esetében tehát az a fơ kérdés, hogy érzelmi válasz kialakulását (emotion trajectory) különbözô folyamatok hogyan befolyásolják (Gross, Sheppes és Urry, 2011). Az érzelemszabályozó folyamatok - amelyek lehetnek automatikusak vagy kontrolláltak, tudatosak vagy éppen tudattalanok (Hopp, Troy és Mauss, 2011; Williams, Bargh, Nocera és Gray, 2009) - az érzelemgeneráló folyamat számos állomásán hathatnak; múködhetnek az érzelem kiváltódása elốtt, után, illetve közben is (Eisenberg és Spinrad, 2004; Gross, 1998; Sheppes és Gross, 2011). Tehát a kutatások fố kérdése az, hogy milyen módon, milyen folyamatok, stratégiák alkalmazásával tudjuk az érzelmek intenzitását, idôi jellemzőit, gyakoriságát, típusát (Thompson, 1994), megjelenési módját és kifejezését (Gross, 1998) különbözó helyzetekben - legyenek azok akár stresszhelyzetek, akár mindennapi helyzetek - befolyásolni. 
Sokféleképpen gondolkozhatunk az érzelemszabályozásról, az intrinzik érzelemszabályozás - Gross (2015) megközelítésében - azt jelenti, hogy a saját érzelmi állapotunk megváltoztatása a cél, míg az extrinzik esetében más - pl. a gyermekünk, barátunk - érzelmének megváltoztatását szeretnénk elérni. Az érzelemszabályozás kapcsán - automatikusan - arra gondolunk, hogy általában arra törekszünk, a negatív érzelmeket csökkentsük, míg a pozitív érzelmeket növeljük, azaz egyfajta hedonikus alapú érzelemszabályozást végezzünk. Ez valószínúleg sok esetben valóban így van, azonban az aktuális, fơként instrumentális céljainktól függôen vagy kulturális szabályok által vezérelten elôfordulhat, hogy egy ellenhedonikus (counterhedonic) szabályozást hajtunk végre: azaz a negatív érzelmeinket fokozni, míg a pozitív érzelmeinket csillapítani szeretnénk. Jó példa lehet erre az, hogy elôadás elôtt a színész, akinek egy szomorú karaktert kell eljátszania, tudatosan elóhívja és fokozza a negatív érzelmeit (Tamir, 2005). Hasonlóan szemléletes példa lehet erre az is, hogy egy nehéz vizsga sikeres letétele utáni örömünket fékeznünk kell - vagy legalábbis illik nem túl erôsen kimutatni -, ha a legjobb barátunk viszont megbukott rajta.

Érdemes itt megemlíteni, hogy mivel az érzelmi válasz többkomponensú folyamatként (1. táblázat) képzelhetô el (Izard, Fine, Mostow, Trentacosta és Campbell, 2002; Scherer, 1982), a szabályozás tulajdonképpen az érzelem bármelyik vagy akár mindegyik komponensére is irányulhat - így például az érzelmi élményre, az érzelem kifejezésére vagy az érzelmeket kísérô testi jelzésekre (pl. gyors szívverés, szapora levegóvétel). Szabályozhatjuk az érzelmi információhoz tartozó érzelmi töltés vagy a személyes relevancia kognitív (ki)értékelését is (azaz a kognitív komponenst) (Green és Malhi, 2006), például az elfogadás vagy átkeretezés stratégia bevetésével. Az érzelmek motivációs komponensének - azaz az adott érzelemhez kapcsolódó cselekvés elókészítésének és kivitelezésének (Scherer, 2005) - szabályozására jó példa lehet, hogy adott esetben a dühhöz kapcsolódó „most mindjárt megütöm” vagy „lekiabálom a fejét” késztetésünket kontrolláljuk.

1. táblázat. Az érzelmek funkciói és összetevői Scherer (2005) nyomán

\begin{tabular}{l|l}
\hline Érzelmi funkció & Érzelmi komponens \\
\hline $\begin{array}{l}\text { A környezet (tárgyak és események) } \\
\text { értékelése }\end{array}$ & Kognitív komponens (értékelés) \\
\hline Rendszerszabályozás & Neurofiziológiai komponens (testi jelzések) \\
\hline A cselekvés elôkészítése és irányítása & $\begin{array}{l}\text { Motivációs komponens } \\
\text { (cselekvési tendenciák) }\end{array}$ \\
\hline $\begin{array}{l}\text { A reakció és a viselkedési szándék } \\
\text { kommunikációja }\end{array}$ & $\begin{array}{l}\text { Motoros kifejezó komponens } \\
\text { (faciális és vokális kifejezés) }\end{array}$ \\
\hline $\begin{array}{l}\text { A belsố állapotok és a szervezet-környezet } \\
\text { interakció monitorozása }\end{array}$ & $\begin{array}{l}\text { Szubjektív érzés komponens } \\
\text { (érzelmi élmény) }\end{array}$ \\
\hline
\end{tabular}




\section{Az érzelemszabályozás folyamatmodellje}

Az érzelemszabályozás-kutatásban meglehetôsen nagy hangsúly helyeződött arra, hogy különbözó stratégiák, illetve az ezekhez tartozó konkrét módszerek, az ún. taktikák (tactics) milyen módon befolyásolják a kialakuló vagy a már kialakult érzelmet. Ehhez keretként leggyakrabban a Gross-féle (1998) folyamatmodellt (1. ábra), illetve annak továbbfejlesztett, ún. kiterjesztett változatát (Gross, 2015) alkalmazzák. A stratégiákat, illetve a szabályozási folyamatokat ugyanis lehet abból a szempontból vizsgálni, hogy az érzelemgenerálódás mely szakaszában lépnek fel.

Az előzményközpontúan alkalmazott stratégiák már az érzelmi információk, azaz az input megváltoztatását célozzák meg, vagyis az érzelemgenerálódás folyamatára gyakorolnak hatást. Idesorolhatjuk a szituációszelekciót, a szituáció módosítását, a figyelem irányítását és a kognitív változtatásokat.

A szituációszelekció azt jelenti, hogy az érzelmeink szabályozása érdekében bizonyos helyzeteket elkerülünk, vagy éppen megközelítünk, vagy akár azokkal konfrontálódunk. Egyszerú példa lehet az elkerülésre az, hogy ha tudjuk, hogy a horrorfilmek után rettenetesen félünk, akkor inkább egy szappanoperát nézünk meg a televízióban.

Előfordulhat azonban, hogy bár a nem kívánt helyzetet és érzelmet nem tudjuk elkerülni, de a szituáció valamely aspektusának módosításával az érzelmi állapotunkat is módosítani tudjuk. Például egy közelgô, számunkra fontos, de ugyanakkor szorongással várt helyzet esetében a baráti társaságunkat kérhetjük, hogy ezt a témát a találkozások alkalmával ne hozzák fel. De Gross (2002) például a szituáció módosításához kapcsolja a problémafókuszú megküzdést (Lazarus és Folkman, 1984) is, amelyet közvetlen szituációmódosításként címkéz, és az elsôdleges kontrollt is (Rothbaum, Weisz és Snyder, 1982): azaz a nem érzelemfókuszú stratégiáknak is lehet egyfajta „mellékhatása” a kibontakozó érzelmi állapotra. Például ha egy közelgô fontos dolgozatra gondolva összeszorul a gyomrunk, akkor koncentrálhatunk a konkrét gyakorlati lépésekre, és elkezdhetünk tanulni.

Egy érzelmet kiváltó helyzetben a figyelmünk irányításával is befolyásolható a kialakuló érzelem: a negatív érzelmekre vagy éppen semleges összetevôkre irányíthatjuk a figyelmünket (az előbbi tulajdonképpen a ruminációt, vagy a hétköznapi szóhasználat szerint a rágódást, míg utóbbi a figyelemelterelést szemlélteti). Gondoljunk csak arra a helyzetre, amikor egy elsố mozis randin nem akarunk sírni a megható jelenet alatt, és inkább a film hátterében megjelenô felhôre koncentrálunk. Ekkor valójában eltereljük a figyelmünket az érzelmi információkról.

A kognitív változtatások (pl. a negatív esemény átkeretezése pozitív vagy semleges terminusokban vagy a negatív érzelmek elfogadása) is az érzelemgenerálódás folyamatában alakítják a keletkező érzelmek minôségét és/vagy intenzitását (Gross, 1998). Érdemes azonban megemlíteni, hogy a kognitív változtatások közé sorolhatók ugyanakkor egyes elhárító mechanizmusok is, hiszen például a tagadás, az izoláció, az intellektualizáció alkalmazása (Gross, 1998) során is az érzelmi élmény személyes relevanciájának átértékelését hajtjuk végre.

A válaszközpontú szabályozás esetén alkalmazott folyamatok vagy stratégiák a már létrejött kimenetel megváltoztatását, vagyis a „kész” érzelem megváltoztatását célozzák meg, így például az érzelmi élmény intenzitásának csökkentését, növelését, meghosz- 
szabbítását, lerövidítését eredményezhetik, vagy az érzelmi élmény kifejezésére gyakorolnak hatást. A válaszközpontú stratégiák közül leggyakrabban az érzelemkifejezés gátlását vizsgálták (Gross és John, 2003), de az érzelmi élmény ebben a szakaszban is számos más stratégiával befolyásolható. Alkalmazhatunk különbözô pszichoaktív szereket, hogy csökkentsük a csalódottságunkat, de elmehetünk futni is vagy jógázni, ha már túlzottan zaklatottak vagyunk. De ha el akarunk még jobban merülni a negatív érzelmeinkben, akkor rágódhatunk is azon, hogy miért is vagyunk mi ilyen szerencsétlenek, vagy visszagondolva az érzelmet kiváltó helyzetre, kereshetünk olyan jelentést, amellyel átkeretezhetjük a történéseket, így csillapítva a dühünket.

Fontos megemlíteni, hogy ez a modell egyfajta átfogó konceptuális modell, és talán jól látható, hogy különbözô stratégiákat (pl. a kognitív átkeretezést) használhatjuk a korai és késôi fázisban is, vagyis az érzelemgenerálódás szakaszában, ill. a már kialakult érzelem befolyásolására is (1. ábra). Míg az eredeti modell az előzményközpontú stratégiák hatékonyságát vetette fel (Gross, 1998), mára ismert, hogy az érzelemszabályozó stratégiák és a hatékonyság közötti kapcsolat bonyolultabb, mint amit a folyamatmodell eredetileg feltételezett (Sheppes és Gross, 2011). Úgy tûnik, hogy attól függôen, hogy milyen egy adott stratégia idôzitése - azaz, hogy az adott stratégiát a kialakuló vagy már létrejött érzelmi élmény módosítására alkalmazzuk -, más következményekkel jár az érzelmi állapot alakulására vonatkozóan. A pozitív átkeretezés például hatékonyabb lehet a korai, mint a késôi fázisban, míg az elterelés (distraction) az idôzítéstôl függetlenül fejti ki hatását (Sheppes és Gross, 2011; Sheppes és Meiran, 2007). Ugyanakkor a szituáció jellege is befolyásolhatja, hogy az átkeretezés haszon-költség aránya milyen. Azt találták egy kutatásban, hogy míg az átkeretezés kontrollálhatatlan stressz esetén valóban kevesebb depresszív tünettel jár, addig kontrollálható stresszorok esetén az átkeretezés inkább több depresszív tünettel társul (Troy és mtsai, 2013). Ráadásul az átkeretezés többféleképpen, azaz többféle taktikával valósulhat meg, például (1) az inger/helyzet jelentésének megváltoztatásával (reinterpretáció) vagy (2) az érzelmi ingertôl/helyzettôl való pszichológiai távolság felvételével (távolítás). Ez utóbbira jó példa lehet az, hogy a munkánkat kritizáló vélemény elolvasása után a negatív érzelmeinket úgy szabályozzuk, hogy elképzeljük, egy semleges, objektív személy hogyan észlelné ezt a szituációt. Míg a reinterpretáció során azt gondolhatjuk, hogy milyen jó, hogy a lektor ilyen jól megkritizálta a munkánkat, hiszen ezzel olyan szempontokat adott, amelyek valójában segítettek (Powers és LaBar, 2019).

Fontos kiemelnünk, hogy az érzelemszabályozás vagy az alkalmazott stratégia hatékonyságát és a kontextushoz kötött adaptivitását egyértelmúen az fogja megmutatni, sikerült-e az adott helyzetben az érzelemszabályozási célunknak megfelelôt kiválasztani és azt végrehajtani. Mindez független lehet attól, hogy az adott stratégia a szociális normáknak megfelelô vagy hosszú távon kedvezô hatásokkal társul-e a fejlôdésünk szempontjából, azaz ilyen értelemben adaptívnak tekinthetốe. Jó példa lehet erre az elkerülés. A negatív érzelmeket kiváltó helyzeteknek, gondolatoknak az elkerülése kiválóan múködô, azaz hatékony stratégia lehet, mivel vagy ki sem bontakozik a negatív érzelem, vagy csökken az intenzitása. Ugyanakkor hosszú távon - és gyakori alkalmazás mellett - az elkerülés gátolhatja a személyes fejlődést, vagy alkalmazkodási problémákat okozhat. Gondoljunk bizonyos szorongásos megbetegedésekre, amelyekben a szorongást kiváltó helyzetek (pl. szociális helyzetek, nyitott terek) elkerülése ugyan 


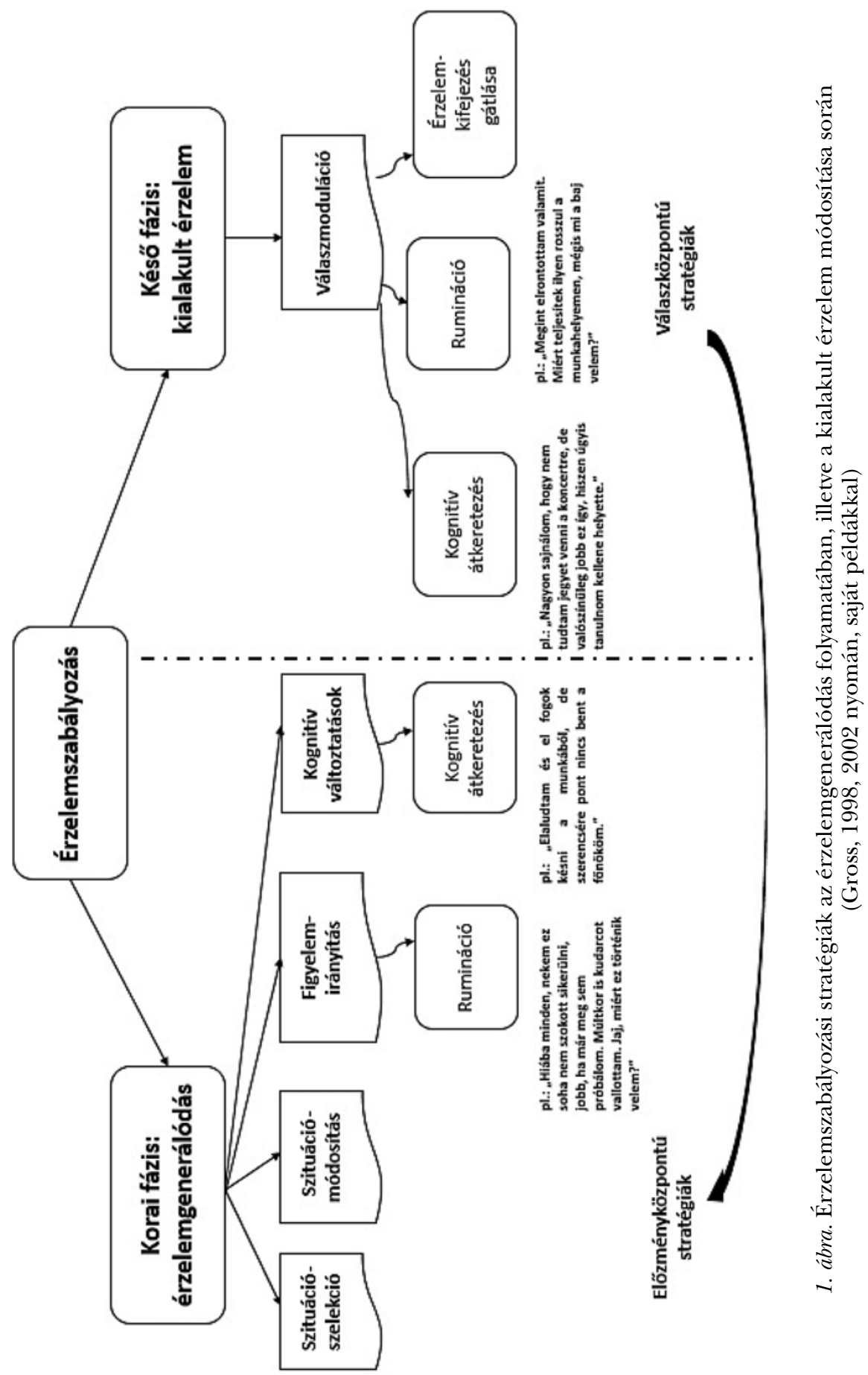


csökkenti a negatív érzelmek aktuális átélését, de hosszú távon megnehezíti, beszúkítheti az egyén életét.

Gross (2015; Sheppes, Suri és Gross, 2015) a meglévô eredmények alapján továbbfejlesztette modelljét. Ebben az új modellben, amely az érzelemszabályozás kiterjesztett folyamatmodellje elnevezést kapta, Gross (2015) az értékelés (valuation) folyamatát emeli ki. Véleménye szerint a szervezetben több szinten folyik a beérkezó inputok/információk értékelése, és a konkrét viselkedést különbözó értékelô rendszerek közötti interakció fogja meghatározni. Érzelemszabályozás akkor lép fel, amikor egy másodfokú értékelô rendszer egy elsôfokú rendszer értékelését (azaz az érzelemgenerálódásban szerepet játszó rendszer értékelését) célozza meg, és azt értékeli jónak (pozitívnak) vagy rossznak (negatívnak). Ezzel olyan cselekvési impulzusok generálódhatnak, amelyek az elsôfokú értékelő rendszer aktivitásának megváltozásával jár(hat) nak. Másként fogalmazva: egy adott szituációban vagy inger hatására létrejövó érzelem is egy értékelési folyamat eredménye. Érzelemszabályozás akkor fog fellépni, ha a létrejött érzelmet a „rendszer” valamilyen okból nem megfeleloonek értékeli, így az elsôdleges cél a kialakult érzelem megváltoztatása lesz. Ebben az értelemben az érzelemszabályozás egy négyszakaszos folyamatként írható le: (1) elôször a szabályozni szükséges érzelmek azonosítása történik meg; (2) majd az adott érzelem szabályozásához szükséges stratégia kiválasztása következik; (3) ezt követi a stratégia implementációja (azaz a konkrét taktika alkalmazása); (4) és végül a stratégia megvalósításának monitorozása és módosítása, ha szükséges.

Minden szakasz további alfolyamatokra bontható (észlelés, értékelés és múvelet [action]), és minden szakaszhoz köthetôk olyan „hibák” is, amelyek az érzelemszabályozás kudarcához (emotion regulation failure) vezetnek, amikor is az érzelem tulajdonképpen szabályozatlan marad. Ugyanakkor az is elófordulhat, hogy olyan szabályozási folyamatot/stratégiát választunk ki, amely inkább - és fooleg hosszabb távon - kárt okoz (misregulation).

Gross (2015) az érzelmi szabályozás elsố alfolyamatában - azaz a szabályozni kívánt érzelmek azonosításának alfolyamatában - érthetô módon az érzelmi (és/vagy interoceptív) tudatosságot és az érzelmekrốl alkotott általános hiedelmek hatását tartja fontosnak. A második alfolyamatban az érzelemszabályozó stratégiák személy által birtokolt repertoárját, ezek értékelését és az érzelemszabályozással kapcsolatban kialakított énhatékonysági hiedelmeket látja kritikusnak. Míg a harmadik szakaszban az játszik főszerepet, hogy képesek vagyunk-e egy absztrakt stratégiát (pl. valahogy meg kellene változtatni a helyzet értelmezését) konkrétan az adott helyzet jellemzőinek ismeretében alkalmazni (pl. nem akart megbántani az ismerôsöm, csak rendkívül fáradt és elkeseredett volt). A negyedik szakaszban pedig azt kell „eldönteni”, hogy mennyi ideig maradjon fenn a szabályozás, le lehet-e már állítani, vagy szükséges máshogyan próbálkozni.

Az érzelemszabályozás kiterjesztett folyamatmodellje szerint tehát az érzelemszabályozás kudarcát többféle folyamat okozhatja. Előfordulhat, hogy az érzelmi folyamatok nem megfelelố percepciója - azaz más szavakkal az érzelmek azonositásában fellépó probléma (vö. alexitímia, Taylor, Bagby és Parker, 1991) - már eleve gátat vet a hatékony érzelemszabályozásnak. De az is elképzelhetô akár, hogy az érzelmekrôl vagy az érzelemszabályozási stratégiákról alkotott hiedelmek - azaz metakogníciók - okoznak 
problémát (pl. ruminációval kapcsolatos pozitív vélekedés depresszióban gátja lehet annak, hogy más stratégiákat is bevessünk) (Papageorgiou és Wells, 2001). Ha kevés rendelkezésre álló stratégia van a személy repertoárjában, akkor nagy eséllyel válik rugalmatlanná az érzelmek szabályozása.

\section{Adaptív érzelemszabályozás - útban az érzelmi intelligencia felé}

Az érzelemszabályozási vizsgálódások során az elméletalkotók igyekeznek elkerülni azt, hogy egy-egy stratégiát eredendốn adaptívnak vagy maladaptívnak tekintsenek, hiszen maga a kontextus, ill. az egyén érzelemszabályozási céljai (legyen az egy extrinzik cél, például hetente többször sportolni vagy egy intrinzik cél, például nyugodtnak maradni) egyértelmúen meghatározhatják a kiválasztott stratégia sikerét vagy hosszú távú „hasznát és költségét”. Ennek megfelelôen a kurrens szakirodalom inkább az érzelemszabályozás flexibilitását hangsúlyozza (Aldao, Sheppes és Gross, 2015). Emellett az adaptív érzelemszabályozás kifejezés is megtalálható a szakirodalomban, és mindkettô megközelítés köthetô az érzelmi intelligencia elméleti és kutatási tradíciójához (lásd alább).

Bridges, Denham és Ganiban (2004) szerint az adaptív érzelemszabályozás teszi lehetốvé a genuin érzelmek átélését és ezeknek olyan módon való kifejezését, amely biztosítja, hogy mind a saját, mind mások érzelemszabályozási céljai (pl. biztonság, pozitív szociális interakciók, észlelt kompetencia) fennmaradhassanak. Ennek fényében tehát a kontextuálisan adaptív (azaz sikeres) stratégia még nem szavatolja azt, legalábbis Bridges és munkatársai (2004) megközelítésében, hogy adaptív érzelemszabályozást végeztünk, vagy érzelmi szempontból intelligensen szabályoztuk az érzelmeinket (vagy az érzelmi válasz valamely komponensét). Kiváló példát kínál erre Pena-Sarrionandia, Mikolajczak és Gross (2015) tanulmánya, amelyben az érzelemszabályozás és az érzelmi intelligencia fogalmát, kutatási módszereit és hagyományait vetik össze. Példájuk szerint, ha egy fốnök a haragjának fokozásával és kimutatásával eléri, hogy a beosztottjai túlórázzanak, akkor a céljait tekintve hatékonyan modulálta az érzelmi állapotának alakulását. Ugyanakkor ez esetben semmiképp nem mondhatjuk, hogy érzelmileg intelligens vagy általánosabb értelemben adaptív megoldást választott, mivel nem volt tekintettel a beosztottak céljaira, állapotára és jóllétére.

\section{ÉRZELEMSZABÁLYOZÁS AZ ÉRZELMI INTELLIGENCIA MEGKÖZELÍTÉSEIBEN}

Az 1990-es években Salovey és Mayer (1990) azt a gondolatot vetették fel, hogy az érzelmekkel kapcsolatos mentális képességek önálló intelligenciaformát alkotnak (lásd errôl részletesen magyarul Nagy, 2012, Nagy, Oláh és G. Tóth, 2009; Nagy, Magyaródi és Séllei, 2015; Oláh, 2005 munkáit). Az érzelmi intelligenciát (a továbbiakban EI) négy részképességre bontották: az érzelmek percepciója, az érzelmek felhasználása, az érzelmek megértése és az érzelmek kezelése (Mayer és Salovey, 1997). Az érzelemszabályozást a pozitív és negatív érzésekre való nyitottsággal, az érzelmek monitorozásának, mérlegelésének képességével, az érzelmek informatív jellegétôl és/vagy 
hasznosságától függôen különbözô érzelmi állapotok generálásának, az érzelmektôl való távolmaradásnak a képességével azonosítják. Továbbá nemcsak a saját, hanem mások érzéseinek kezelését is az érzelemszabályozáshoz sorolják. Alapvetôen az érzelmek kezelését tudásalapúnak (de nem feltétlenül tudatosnak), reflektívnek és kognitív irányításúnak képzelik el (Mayer, Salovey, Caruso és Sitarenios, 2001; Salovey, Mayer és Caruso, 2002). Oláh (2005) megfogalmazásában például „az érzelmi intelligencia az érzelmi életünk feletti uralmat, a társas kapcsolatokban jelentkezó érzelmi történések és folyamatok kezelését, irányítását biztosító képességeink együttese" (169).

Érdemes megemlíteni azonban, hogy az érzelmiintelligencia-kutatások elsôsorban nem arra koncentráltak, hogy az érzelemszabályozás alapvetô folyamatait vizsgálják, hanem inkább arra, hogy az EI-ben megnyilvánuló egyéni különbségeknek milyen kimenetelei vannak a mindennapi életben (Pena-Sarrionandia és mtsai, 2015). Az érzelmi intelligencia „szintjéről” vagy önbeszámolóval nyernek információt a kutatásokban (ez a vonásalapú megközelítés), vagy „teljesítményteszttel” mérik az EI négy részképességét. Martins, Ramalho és Morin (2010) metaanalízisükben kimutatták, hogy az érzelmi intelligencia magasabb szintje jobb egészségmutatókkal társul, és ez a képességalapú teszttel mért EI esetében is fennállt (bár a kapcsolat kevésbé volt erôs).

Az EI-szakirodalom általánosságban nem azt vizsgálja, hogy az önmagukat érzelmileg intelligensnek tartó személyek vagy a képességmérésen magas pontszámot eléró személyek milyen stratégiákat használnak, és a való életben valóban hatékonyak-e, vagy egyáltalán rugalmasak-e az érzelmek szabályozásában. Éppen ezért Pena-Sarrionandia és munkatársai (2015) azt javasolják, hogy az érzelemszabályozás folyamataira irányuló kutatásokat és az érzelmiintelligencia-kutatásokat érdemes lenne ötvözni, hogy jobban rálássunk azokra az érzelemszabályozási folyamatokra, amelyek megbújnak az érzelmileg intelligens múködés hátterében. A Gross-féle folyamatmodellt alapul véve olyan kutatásokat kerestek összefoglaló tanulmányukban, amelyekben az EI bevett mérései mellett legalább egy érzelemszabályozási stratégiát is vizsgáltak. Ugyanakkor nehéz az összefoglaló tanulmányukból bármi konkrét következtetést levonni, ugyanis a két tradíciót ötvözố kutatások többsége - több mint a 80\%-a - önbeszámolóval mérte az érzelmi intelligenciát.

Egy újabb vizsgálatban (Bucich és MacCann, 2019) élményvételi eljárással (experience sampling method) mérték a mindennapokban használt érzelemszabályozási stratégiákat, pl. az átkeretezést, a ruminációt, a közvetlen szituációmódosítást, az érzelmek másokkal való megosztását és a vonásalapú, illetve a képességalapú EI közötti összefüggéseket. Vizsgálatuk eredményei szerint a képességalapú EI nem, de a vonásalapú EI összefüggött az átkeretezés, a közvetlen szituációmódosítás és az érzelmek másokkal való megosztása érzelemszabályozási szándékkal, stratégiákkal. Ezeket az eredményeket lehet úgy is értékelni, hogy az EI-ra vonatkozó hiedelmek fontosabbak, mint maguk a képességek, de tekintve, hogy a mindennapos érzelemszabályozási stratégiákról is önbeszámolóval kaptak adatokat a kutatók, az együtt járást a közös módszer (azaz az önbeszámolós jelleg) is eredményezhette. Ugyanakkor ez a kutatás is rámutatott arra, hogy gyümölcsözó lenne a két kutatási tradíció ötvözése, azonban módszertani fejlesztésre mindenképpen szükség lenne mindkét oldalon. 


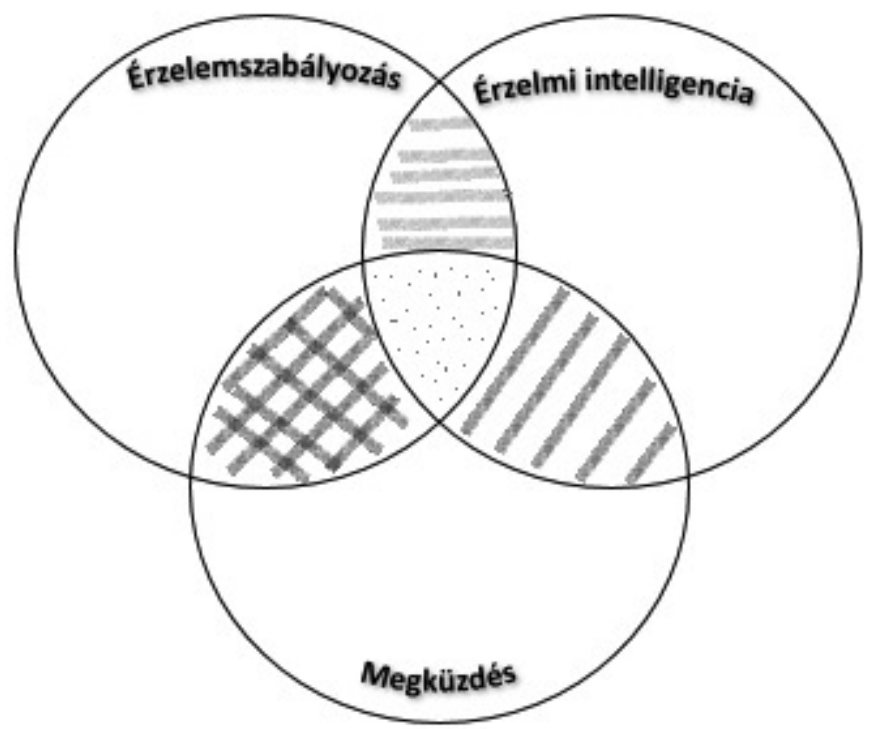

2. ábra. Az érzelemszabályozás, megküzdés és érzelmi intelligencia „kapcsolata”, közös metszetei

Jó példának tûnik a két kutatási tradíció ötvözésére egy újabb vizsgálat, amelyben a szándékosan generált érzelmi állapotok - mint érzelemszabályozási folyamatok - és az EI összefüggéseit vizsgálták. Nevezetesen Zysberg és Raz (2019) arra kérték a résztvevôket, hogy elôször generáljanak izgatottságot, majd pedig, hogy nyugtassák le magukat. (Gondoljunk csak bele: ezek egész hétköznapi folyamatoknak is tekinthetôk: van, hogy fel kell „spannolni” magunkat egy feladatra, egy meccsre, egy találkozásra, és van, hogy éppen le kell nyugtatni magunkat.) Az érzelmek generálása közben a kutatók szívritmust és vérnyomást is mértek, azaz nem hagyatkoztak egyszerúen a résztvevốk önbeszámolójára az érzelemszabályozási feladat sikerességét tekintve. Az érzelmi intelligenciát önbeszámolóval és képességtesztekkel is mérték. Fontos eredményük, hogy a képességalapú EI volt az, amely a két vizsgálati feltételben (izgatottság vs. nyugalom) mért szívritmuskülönbséggel szignifikáns összefüggést mutatott. Ezek az eredmények is megerốsítik, hogy érdemes az érzelemszabályozás kutatásaiból olyan paradigmákat választani, amelyekkel feltárható, hogy a magasabb EI folyamatszinten mit jelenthet. Érdemes ezzel összefüggésben még egy szisztematikus áttekintố tanulmány eredményeit is idézni. Gutierrez-Cobo, Cabello és Fernandez-Berrocal (2016) azt találták, hogy a képességalapú EI a meleg végrehajtó funkciókat - azaz az érzelmi információk szabályozását (Zelazo és Müller, 2002) - mérô kognitív teszteken nyújtott teljesítménnyel szignifikáns kapcsolatban állt, de a hideg végrehajtó funkciókat mérô tesztek teljesítményével nem volt összefüggésben. Valamint a vonásalapú EI tesztek esetében nem volt kapcsolat egyik típusú, végrehajtó funkciókat mérô feladaton nyújtott teljesítménnyel sem. Mindez újfent felhívja a figyelmet arra, hogy valóban 
gyümölcsözô lenne az érzelmileg intelligens érzelemszabályozás folyamatait behatóbban tanulmányozni olyan kutatásokban, amelyek ötvözik az érzelmiintelligencia- és az érzelemszabályozás-kutatások módszereit.

\section{ÖSSZEFOGLALÁS ÉS KITEKINTÉS}

Fontosnak tartjuk újfent hangsúlyozni, hogy célunk nem a megküzdés és az érzelmi intelligencia szakirodalmának ismertetése volt, hanem inkább arra koncentráltunk, hogy az érzelemszabályozás egyik vezetô elméleti modelljét elhelyezzük ezeknek az elméleti és kutatási irányoknak a kontextusában. Az érzelemszabályozás tehát vizsgálható egyrészt stresszhelyzetben - s ilyenkor egyfajta megküzdési módként is számontartható, de vizsgálható saját jogán is, és az érzelmileg intelligens múködésmód keretében is (2. ábra). Számos releváns és izgalmas témára azonban az érzelemszabályozás kapcsán nem tudtunk kitérni. Például nem tárgyaltuk, hogy milyen tényezôk alakítják az érzelemszabályozási folyamatokat és képességeket a fejlôdés során, milyen neurális háttere van az érzelemszabályozási folyamatoknak, illetve milyen módszertannal ismerhetôk meg az érzelemszabályozási folyamatok.

Fontosnak tartjuk még kiemelni, hogy úgy látjuk, alapvetôen mindhárom kutatási tradíció egyetért abban, hogy a magas distressz vagy a negatív érzelmek fokozott elôfordulása vagy nagyon erôs intenzitása nem feltétlenül jelenti azt, hogy az adott egyén rosszul szabályozza az érzelmeit. Hasonlóképpen a distressz hiánya egy adott szituációban még nem szavatolja, hogy az egyén kiváló érzelemszabályozó stratégiákkal vagy képességekkel rendelkezik. A háromféle kutatási irány prominens képviselôi azt sem állítják, hogy a negatív érzelmek mindig rosszak, és azoktól meg kell szabadulni. A negatív érzelmeink, állapotaink felismerésének (és elfogadásának) képessége fontos információkkal láthat el minket. Az enyhe depresszív hangulat például jelölheti, hogy a cél elérhetetlen számunkra (Dickson, Moberly, O’Dea és Field, 2016), vagy megsértettünk egy minimális elvárást/követelményt (lásd Higgins, 1987, elvárt-aktuális énkép diszkrepancia elképzelését), továbbá segíthet döntéseink meghozatalában (lásd Damasio, 1994, szomatikus marker elképzelését).

Hasonlóképpen, a pozitív érzelmek szabályozásának - azaz generálásának, fenntartásának, fokozásának és csökkentésének - kérdéskörét, bármelyik említett kutatási irányból is közelítünk hozzá, érdemes lenne tovább vizsgálni. A pozitív érzelmek szabályozásának különösen nagy jelentôsége van akkor, ha egy stresszteli idôszakkal nézünk szembe. Ebben az idôszakban az önmotiválás képessége (amit Goleman, 1997, az érzelmi intelligencia összetevői között tart számon) a mindennapi aktivitásokkal generált pozitív érzelmekhez való hozzáférés erôforrásaként értékelhető (Trope, Ferguson és Raghunathan, 2001), mert optimálisan befolyásolja az információfeldolgozást.

Bármilyen elméleti keretet és módszertant választunk is az érzelemszabályozás folyamatának jobb megértéséhez, fontos észben tartanunk az ökológiai validitás kérdését. A valódi kérdés tehát az, hogy a különbözô módokon (pl. a laborban, az önbeszámolós kérdőívvel, hipotetikus szituációk értékelésével) nyert eredményeknek van-e a mindennapokban megfigyelhetô viselkedéssel és funkcionálással bármilyen jelentôs kapcsolata. 


\section{KÖSZÖNETNYILVÁNÍTÁS}

A tanulmány a Nemzeti Kutatási, Fejlesztési és Innovációs Hivatal (FK 128614) támogatásával, illetve a Nemzeti Agykutatási Program (2017-1.2.1-NKP-2017-00002) támogatásával készült.

\section{IRODALOM}

Aldao, A., Nolen-Hoeksema, S., \& Schweizer, S. (2010). Emotion-regulation strategies across psychopathology: A meta-analytic review. Clinical Psychology Review, 30(2), 217-237.

Aldao, A., Sheppes, G., \& Gross, J. J. (2015). Emotion Regulation Flexibility. Cognitive Therapy and Research, 39(3), 263-278.

Boersma, K., Sodermark, M., Hesser, H., Flink, I. K., Gerdle, B., \& Linton, S. J. (2019). Efficacy of a transdiagnostic emotion-focused exposure treatment for chronic pain patients with comorbid anxiety and depression: a randomized controlled trial. Pain, 160(8), 1708-1718.

Bridges, L. J., Denham, S. A., \& Ganiban, J. M. (2004). Definitional issues in emotion regulation research. Child Development, 75(2), 340-345.

Bucich, M., \& MacCann, C. (2019). Emotional Intelligence and Day-To-Day Emotion Regulation Processes: Examining Motives for Social Sharing. Personality and Individual Differences, 137, 22-26.

Compas, B. E., Jaser, S. S., Bettis, A. H., Watson, K. H., Gruhn, M. A., Dunbar, J. P. et al. (2017). Coping, Emotion Regulation, and Psychopathology in Childhood and Adolescence: A Meta-Analysis and Narrative Review. Psychological Bulletin, 143(9), 939-991.

Damasio, A. R. (1994). Descartes' error: emotion, reason, and the human brain. New York: Grosset/ Putnam.

Dickson, J. M., Moberly, N. J., O’Dea, C., \& Field, M. (2016). Goal Fluency, Pessimism and Disengagement in Depression. Plos One, 11(11).

Eisenberg, N., \& Spinrad, T. L. (2004). Emotion-related regulation: Sharpening the definition. Child Development, 75(2), 334-339.

Fernandez, K. C., Jazaieri, H., \& Gross, J. J. (2016). Emotion Regulation: A Transdiagnostic Perspective on a New RDoC Domain. Cognitive Therapy and Research, 40(3), 426-440.

Goleman, D. (1997). Érzelmi intelligencia. Budapest: Háttér Kiadó.

Gortner, E. M., Rude, S. S., \& Pennebaker, J. W. (2006). Benefits of expressive writing in lowering rumination and depressive symptoms. Behavior Therapy, 37(3), 292-303.

Gratz, K. L., Bardeen, J. R., Levy, R., Dixon-Gordon, K. L., \& Tull, M. T. (2015). Mechanisms of change in an emotion regulation group therapy for deliberate self-harm among women with borderline personality disorder. Behaviour Research and Therapy, 65, 29-35.

Green, M. J., \& Malhi, G. S. (2006). Neural mechanisms of the cognitive control of emotion. Acta Neuropsychiatrica, 18(3-4), 144-153.

Gross, J. J. (1998). The emerging field of emotion regulation. Review of General Psychology, 2, 271-299.

Gross, J. J. (2002). Emotion regulation: Affective, cognitive, and social consequences. Psychophysiology, 39(3), 281-291.

Gross, J. J. (2015). Emotion Regulation: Current Status and Future Prospects. Psychological Inquiry, 26(1), 1-26.

Gross, J. J., \& John, O. P. (2003). Individual differences in two emotion regulation processes: Implications for affect, relationships, and well-being. Journal of Personality and Social Psychology, 85(2), 348-362. 
Gross, J. J., Sheppes, G., \& Urry, H. L. (2011). Cognition and Emotion Lecture at the 2010 SPSP Emotion Preconference Emotion generation and emotion regulation: A distinction we should make (carefully). Cognition \& Emotion, 25(5), 765-781.

Gutierrez-Cobo, M. J., Cabello, R., \& Fernandez-Berrocal, P. (2016). The Relationship between Emotional Intelligence and Cool and Hot Cognitive Processes: A Systematic Review. Frontiers in Behavioral Neuroscience, 10. doi:10.3389/fnbeh.2016.00101

Higgins, E. T. (1987). Self-discrepancy - a theory relating self and affect. Psychological Review, 94(3), 319-340.

Hopp, H., Troy, A. S., \& Mauss, I. B. (2011). The unconscious pursuit of emotion regulation: Implications for psychological health. Cognition $\mathcal{E}^{2}$ Emotion, 25(3), 532-545.

Izard, C. E., Fine, S., Mostow, A., Trentacosta, C., \& Campbell, J. (2002). Emotion processes in normal and abnormal development and preventive intervention. Development and Psychopathology, 14(4), 761-787.

Lazarus, R. (1991). Emotion and adaptation. New York: Oxford University Press.

Lazarus, R. S., \& Folkman, S. (1984). Stress, Appraisal, and Coping. New York: Springer.

Lazarus, R. S., \& Opton, E. M., Jr. (1966). The study of psychological stress: A summary of theoretical formulations and experimental findings. In C. D. Spielberger (Ed), Anxiety and behavior (pp. 225-262). New York: Academic Press.

Martins, A., Ramalho, N., \& Morin, E. (2010). A comprehensive meta-analysis of the relationship between Emotional Intelligence and health. Personality and Individual Differences, 49(6), $554-564$.

Mayer, J. D. \& Salovey, P. (1997). What is emotional intelligence? In P. Salovey \& D. Sluyter (Eds), Emotional development and emotional intelligence (pp. 3-31). New York: Basic Books.

Mayer, J. D., Salovey, P., Caruso, D. R. \& Sitarenios, G. (2001). Emotional intelligence as a standard intelligence. Emotion, 3, 232-242.

Nagy, H. (2012). A Salovey-Mayer-féle érzelmi intelligencia modell érvényességének elemzése. Magyar Pszichológiai Szemle, 67(1), 105-127.

Nagy, H., Magyaródi, T. \& Séllei, B. (2015). A képességalapú érzelmi intelligencia: új paradigmák a tesztfejlesztésben és pontozásban. Hazai tapasztalatok az érzelemmegértés és érzelemszabályozás szituációs tesztekkel. Magyar Pszichológiai Szemle, 70(4), 827-846.

Nagy, H., Oláh, A., \& G. Tóth, K. (2009). Az érzelmi intelligencia mérésének néhány problémája a fejlốdési kritérium tesztelése. Pszichológia, 29(2), 165-186.

Oláh, A. (2004). Megküzdés és pszichológiai immunitás. In Pléh, Cs. \& Boross, O. (Szerk.), Bevezetés a pszichológiába (pp. 631-664). Budapest: Osiris Kiadó.

Oláh, A. (2005). Érzelmek, megküzdés és optimális élmény. Budapest: Trefort Kiadó.

Papageorgiou, C., \& Wells, A. (2001). Metacognitive beliefs about rumination in recurrent major depression. Cognitive and Behavioral Practice, 8(2), 160-164.

Pena-Sarrionandia, A., Mikolajczak, M., \& Gross, J. J. (2015). Integrating emotion regulation and emotional intelligence traditions: a meta-analysis. Frontiers in Psychology, 6. doi:10.3389/ fpsyg.2015.00160

Powers, J. P., \& LaBar, K. S. (2019). Regulating emotion through distancing: A taxonomy, neurocognitive model, and supporting meta-analysis. Neuroscience and Biobehavioral Reviews, 96, $155-173$.

Rothbaum, F., Weisz, J. R., \& Snyder, S. S. (1982). Changing the world and changing the self - A 2-process model of perceived control. Journal of Personality and Social Psychology, 42(1), $5-37$.

Salovey, P., \& Mayer, J. D. (1990). Emotional Intelligence. Imagination, Cognition and Personality, 9(3), 185-211. 
Salovey, P., Mayer, J. D. \& Caruso, D. (2002). The positive psychology of emotional intelligence. In Synder, C. R. \& Lopez, S. J. (Eds), The Handbook of Positive Psychology (pp. 159-171). New York: Oxford University Press.

Scherer, K. R. (1982). Emotion as a process - function, origin, and regulation. Social Science Information Sur Les Sciences Sociales, 21(4-5), 555-570.

Scherer, K. R. (2005). What are emotions? And how can they be measured? Social Science Information Sur Les Sciences Sociales, 44(4), 695-729.

Sheppes, G., \& Gross, J. J. (2011). Is Timing Everything? Temporal Considerations in Emotion Regulation. Personality and Social Psychology Review, 15(4), 319-331.

Sheppes, G., \& Meiran, N. (2007). Better late than never? On the dynamics of online regulation of sadness using distraction and cognitive reappraisal. Personality and Social Psychology Bulletin, 33(11), 1518-1532.

Sheppes, G., Suri, G., \& Gross, J. J. (2015). Emotion Regulation and Psychopathology. Annual Review of Clinical Psychology, 11(1), 379-405.

Sloan, E., Hall, K., Moulding, R., Bryce, S., Mildred, H., \& Staiger, P. K. (2017). Emotion regulation as a transdiagnostic treatment construct across anxiety, depression, substance, eating and borderline personality disorders: A systematic review. Clinical Psychology Review, 57, $141-163$.

Tamir, M. (2005). Don't worry, be happy? Neuroticism, trait-consistent affect regulation, and performance. Journal of Personality and Social Psychology, 89(3), 449-461.

Taylor, G. J., Bagby, R. M., \& Parker, J. D. (1991). The alexithymia construct. A potential paradigm for psychosomatic medicine. Psychosomatics, 32(2), 153-164.

Thompson, R. A. (1994). Emotion regulation: A theme in search of definition. Monographs of the Society for Research in Child Development, 59(2-3), 25-52.

Trope, Y., Fergusson, M. \& Raghunathan, R. (2001). A hangulatok szerepe az önmagunkról szóló információk feldolgozásában. In Forgács, J. Az érzelmek pszichológiája (pp. 253-269). Budapest: Kairosz Kiadó.

Troy, A. S., Shallcross, A. J., \& Mauss, I. B. (2013). A Person-by-Situation Approach to Emotion Regulation: Cognitive Reappraisal Can Either Help or Hurt, Depending on the Context. Psychological Science, 24(12), 2505-2514.

Wallace, L. M., Masson, P. C., Safer, D. L., \& Von Ranson, K. M. (2014). Change in emotion regulation during the course of treatment predicts binge abstinence in guided self-help dialectical behavior therapy for binge eating disorder. Journal of Eating Disorder, 2(1), 35.

Watkins, E. R., \& Nolen-Hoeksema, S. (2014). A habit-goal framework of depressive rumination. Journal of Abnormal Psychology, 123(1), 24-34.

Williams, L. E., Bargh, J. A., Nocera, C. C., \& Gray, J. R. (2009). The Unconscious Regulation of Emotion: Nonconscious Reappraisal Goals Modulate Emotional Reactivity. Emotion, 9(6), 847-854.

Zelazo, P. D. \& Müller, U. (2002). Executive Function in Typical and Atypical Development. In U. Goswami (Ed), Handbook of Childhood Cognitive Development (pp. 445-469). Oxford: Blackwell.

Zysberg, L., \& Raz, S. (2019). Emotional intelligence and emotion regulation in self-induced emotional states: Physiological evidence. Personality and Individual Differences, 139, 202-207. 


\section{EMOTION REGULATION - IN THE CONTEXT OF COPING AND EMOTIONAL INTELLIGENCE LITERATURE: THREE DISTINCT YET OVERLAPPING THEORETICAL AND EMPIRICAL TRADITIONS

\author{
KÖKÖNYEI, GYÖNGYI - KOCSEL, NATÁLIA
}

Properly managed emotional processes have crucial role in the adaptation to environmental demands and in the maintenance of optimal everyday functioning. For this reason, it is important to determine those methods, situations, strategies, abilities or skills by which a person could effectively manage his/her emotions. The aim of this theoretical paper is to investigate the associations and differences of emotional regulation with coping and emotional intelligence literature from the perspective of the Process Model of Emotion Regulation. Beyond the description of the theoretical models, we demonstrate the different processes and strategies through concrete examples; and we deal with the issues of adaptive-maladaptive emotion regulation and positive emotion regulation. Finally, we cite some current empirical results and highlight the importance of ecological validity in emotion regulation research.

Keywords: emotion regulation, coping, emotional intelligence, Process Model of Emotion Regulation, flexibility

A cikk a Creative Commons Attribution 4.0 International License (https://creativecommons. org/licenses/by/4.0) feltételei szerint publikált Open Access közlemény, melynek szellemében a cikk bármilyen médiumban szabadon felhasználható, megosztható és újraközölhetô, feltéve, hogy az eredeti szerzố és a közlés helye, illetve a CC License linkje és az esetlegesen végrehajtott módosítások feltüntetésre kerülnek. (SID_1) 